\title{
4 Man and Society
}

\subsection{Ethical and Social Principles That Govern Life in Society}

The structure of the Universal Constitution, outlined by Dobruska, has its roots in natural law, which serves as a model for the various positive rights. In the following we will seehow our author takes up some theories of the leading exponents of natural law of the seventeenth and eighteenth centuries, while at the same time elaborating new conceptual schemes.

Among the naturalists active in the seventeenth century were Johannes Althusius (1563-1638) and Ugo Grotius (1583-1645), ${ }^{196}$ followed by Thomas Hobbes (1588-1679), ${ }^{197}$ Baruch Spinoza (1632-1677), Samuel von Pufendorf (1632-1694), and Christian Thomasius (1655-1728). Montesquieu, Locke, Rousseau, and Kant belong to the Enlightenment phase.

Although there are multiple currents of thought within natural law, which even stand in contrast to each other, they are all based on two main theses.

The first thesis is that, in addition to the "positive" law conceived and implemented by men, there is also a non-positive law implicit in "nature".

The second thesis sees natural law as axiologically superior to positive law, so much so that positive law deserves obedience only if it adheres to natural law. ${ }^{198}$ The concept of natural law presupposes that there are "norms, which do not depend on the will, but simply on knowledge: norms that can be derived from knowledge of "nature" (the nature of man or the nature of things, as the case may be)". 199

Starting from these two theses, many exponents of seventeenth- and eighteenth-century natural law share a "model" for the construction of a State and its necessary regulatory framework, characterized by the following three elements.

The first element deals with the idea of a state of nature, a state that precedes the polis, i.e. which is pre-political. Individuals in the state of nature are autonomous and, for some thinkers, among them Rousseau, are also free. Almost no natural lawmaker conceives this state of nature as historically located.

196 See for example, Guido Fassò, Storia della filosofia del diritto. II. L'età moderna (BariRoma: Laterza 2001, I. ed. 1968), 81; Antonella Barberini, "La proprietà della Costituzione," Proprietà e diritti reali, Vol. 1 (2011): 47.

197 Norberto Bobbio, "Hobbes e il Giusnaturalismo," Rivista critica di storia della filosofia 17 (1962), 470.

198 Ibidem, 475.

199 Riccardo Guastini, "Sulla validità della costituzione dal punto di vista del positivismo giuridico,” Rivista internazionale di filosofia del diritto 66 (1989): 426. 
The second constituent element is the pact, or social contract. This is the instrument with which the State is founded, through which civil laws replace natural laws. It must be said that each author fleshes out this model in a different way, according to his own anthropological and political conception. Finally, this social pact gives rise to the last element, namely the State.

Dobruska clearly fits into this current of thought and has four main points of interest: (1) the state of nature, (2) the social contract, (3) the state of culture or society, (4) the democratic State. As we can see, with respect to the tripartite scheme of natural law, our author also devotes particular attention to a further step, namely the clarification of the state of society.

\subsection{The State of Nature}

Like most jusnaturalists, Dobruska conceives the state of nature as a pre-social condition, not historically and geographically determined.

In the state of nature (Naturzustand), man (Naturmensch), like other living beings, is free and has an instinct for self-preservation and propagation of his own species. He moves freely in the forests, is able to get food, lives in caves, ${ }^{200}$ and is able to defend himself from aggression. He hasn't developed a language yet, because he doesn't need it to communicate with other human beings. He is in fact completely autonomous, independent, perfect and sovereign. ${ }^{201}$

Precisely because of this autonomy, man is not forced, in the state of nature, to relate to other human beings, in respect of whom he has not developed his own morals. He's selfish, because he doesn't have to give anything to his fellow men. ${ }^{202}$

The only duty that nature imposes on him is towards himself, towards his own physical body. Towards himself he has a "duty of relationship", a duty of reciprocity, aimed at achieving his own goal: self-preservation or individual conservation. $^{203}$

In the state of nature, all men enjoy the most perfect equality. That is to say, they have the same natural rights and equal access to resources; no one has special private rights and no one is treated preferentially.

200 Dobruska, Philosophie sociale, 83.

201 Ibidem, 144.

202 Ibidem, 70 also 83.

203 Ibidem, 105, 116. 
Unlike the English natural law philosopher Thomas Hobbes, Dobruska believes that men, in their natural state, are not equal to each other in terms of skills and competences.

In the thirteenth chapter of Leviathan, Hobbes reminds us that men are equal in both their bodily and spiritual faculties:

Nature hath made men so equall, in the faculties of nature body, and mind; as that though there bee found one man sometimes manifestly stronger in body, or of quicker mind then another; yet when all us reckoned together, the difference between man, and man, is not so considerable, as that one man can thereupon claim to himselfe any benefit, to which another may not pretend, as well as he. For as to the strength of body, the weakest has strength enough to kill the strongest, either by secret machination, or by confederacy with others, that are in the same danger with himselfe. And as to the faculties of the mind, (setting aside the arts grounded upon words, and especially that skill of proceeding upon generall, and infallible rules, called Science; which very few have, and but in few things; as being not a native faculty, born with us; nor attained, (as Prudence,) while we look after somewhat els,) I find yet a greater equality amongst men, than that of strength. For Prudence, is but Experience; which equall time, equally bestowes on all men, in those things they equally apply themselves unto. ${ }^{204}$

Dobruska, on the other hand, believes that men, although belonging to the same species, differ in their body, intellectual abilities and customs. Equality in physical strength and ability would be for Dobruska "against nature":205

Has nature ever created two beings of the same species, in a perfectly identical form? In the inequality of nuances, [nature] varies itself infinitely and struggles at every moment to create new inventions, so much so that it seems to hate mechanical and laborious equality. ${ }^{206}$

For Hobbes, equality also means having the same ends; that is why men are in bitter competition with each other:

From this equality of ability, ariseth equality of hope in the attaining of our Ends. And therefore if any two men desire the same thing, which neverthelesse they cannot both enjoy, they become enemaes; and in the way to their End, (which Is princlpally their owne conservation, and sometimes thetr delectation only,) endeavor to destroy, or subdue one an other. ${ }^{207}$

204 Thomas Hobbes, Leviathan, I. 13 (London: Crooke, 1651, 60-61).

205 Dobruska, Philosophie sociale, 189.

206 Ibidem, 208: [Créa-t-elle jamais deux êtres de là même espèce, d'une forme parfaitement égale? elle qui, dans l'inégalité de ses nuances, se varie jusqu'à l'infini, et qui se fatigue pour ainsi dire à chaque instant pour des inventions nouvelles, tant elle paroît haïr l'égalité méchanique et fatiguante].

207 Hobbes, Leviathan, 61. 
Dobruska agrees instead with the diversity postulated by Montesquieu, ${ }^{208}$ and with the physical inequality of Rousseau. Precisely because they are not equal in their abilities, even though they are able, in their natural state, to preserve themselves without the help of other human beings, ${ }^{209}$ men are not in perpetual conflict with each other. So don't say, with Hobbes, homo homini lupus.

At the same time, Dobruska does not share the philosopher's vision of a lost paradise, as Rousseau did. For the latter, in the state of nature, man is not evil, but capable of mercy and compassion, carrying an innate instinct not to make his fellow man suffer. Rousseau observes, in his Discourse on the Origins of Inequality:

Let us conclude then that man in a state of nature, wandering up and down the forests, without industry, without speech, and without home, an equal stranger to war and to all ties, neither standing in need of his fellow-creatures nor having any desire to hurt them, and perhaps even not distinguishing them one from another; let us conclude that, being self-sufficient and subject to so few passions, he could have no feelings or knowledge but such as befitted his situation; that he felt only his actual necessities, and disregarded everything he did not think himself immediately concerned to notice, and that his understanding made no greater progress than his vanity. ${ }^{210}$

For Dobruska, men in the state of nature are neither only good, as for Rousseau, nor only hostile and warlike, as for Hobbes. They do not have any peculiar moral qualities. On the contrary, in their natural state, human beings, as we have just seen, are selfish; they only think of themselves, they act in their own interest and they owe nothing to others.

It should be noted that Dobruska, when speaking of the être-homme, never seems to consider women. The female world does not have a specific space in his intellectual horizon.

During the years of the French Revolution, women played an important role; in the eighteenth century there were also important thinkers, both in

208 Raymond Aron, Les étapes de la pensée sociologique. Montesquieu, Comte, Marx, Tocqueville, Durkheim, Pareto, Weber, 81.

209 Rousseau, Discours sur l'origine et les fondements de l'inégalité, 1-2 (Idem, A Discourse on a Subject, 174).

210 Ibidem, 84-85: [Concluons qu'errant dans les forêts sans industrie, sans parole, sans domicile, sans guerre, et sans liaisons, sans nul besoin de ses semblables, comme sans nul désir de leur nuire, peut-être même sans jamais en reconnaître aucun individuellement, l'homme sauvage sujet à peu de passions, et se suffisant à lui-même, n'avait que les sentiments et les lumières propres à cet état, qu'il ne sentait que ses vrais besoins, ne regardait que ce qu'il croyait avoir intérêt de voir, et que son intelligence ne faisait pas plus de progrès que sa vanité] (Idem, A Discourse on a Subject, 203). 
France - think Olympe de Gouges (1748-1793) - and in England - think Mary Wollstonecraft (1759-1797). Dobruska doesn't seem to have been influenced in any way by this.

\subsection{The Social Contract}

Dobruska conceives in a different way from Hobbes the motivation that pushes men to leave the state of nature, live in society and sign the social contract. He believes that, with the signing of the pact, men become members first and foremost of a society, and not, as Hobbes thought, of a political corpus. For Dobruska, this society is equivalent to a "social ego" (moi sociale - Rousseau called it moi commun ${ }^{211}$ ).

The drive to sign the social pact comes from the lack of self-sufficiency and autonomy which characterizes human beings in the state of culture. Out of the autonomy they enjoyed in the state of nature, individuals need their peers to ensure self-preservation, or "individual biological existence". ${ }^{212}$ On the other hand, living in society offers human beings two great and significant advantages. Only in the state of society do they have the opportunity to develop and strengthen their desires and intellectual and material abilities at the highest levels.

As we know, for Hobbes, the drive towards society was of a completely different origin. The social pact was necessary in order to guarantee stability to the State and to avoid the strong conflict between men, who are ready to subdue or even eliminate their fellow men in order to achieve their own goals. Hobbes conceives men both as thirsty for power and glory, as well as having a strong need for security. We read about it in the Leviathan:

211 Rousseau, Du contrat social, I. 6: [À l'instant, au lieu de la personne particulière de chaque contractant, cet acte d'association produit un corps moral et collectif composé d'autant de membres que l'assemblée a de voix, lequel reçoit de ce même acte son unité, son moi commun, sa vie et sa volonté] (Idem, The Social Contract, 15: "At once, in place of the individual personality of each contracting party, this act of association creates a moral and collective body, composed of as many members as the assembly contains votes, and receiving from this act its unity, its common identity, its life and its will”). Cf. Tracy B. Strong, Jean-Jacques Rousseau. The Politics of the Ordinary (Lanham: Rowman \& Littlefield, 2002, I ed. 1994), 80.

212 George H. Sabine, A History of Political Theory, revised by T. Landon Thorson, Fourth edition, (Hinsdale: Dryden Press, 1973) (I. ed. 1937), 463. 
So that in the first place, I put for a generall inclination of all mankind, a perpetuall and restlesse desire of Power after power, that ceaseth onely in Death. And the cause of this, is not alwayes that a man hopes for a more intensive delight, than he has already attained to, or that he cannot be content with a moderate power: but because he cannot assure the power and means to live well, which he hath present, without the acquisition of more. ${ }^{213}$

For Dobruska, individuals derive a second benefit from living in society: they become citizens, equal bearers of inviolable rights such as the right to freedom and equality.

The contrast with naturalist thinkers of the past, such as Hobbes and Locke, is remarkable. The latter considered that the individuals who adhered to the pact had natural rights, which they had to renounce, as a result of the choice to establish themselves as a community (pactum unionis), to give life to the political society (pactum subiectionis). For Dobruska, along with Rousseau, individual rights are not transferred in full to the Sovereign. Rousseau affirms in his Social Contract:

From whatever side we approach our principle, we reach the same conclusion, that the social compact sets up among the citizens an equality of such a kind, that they all bind themselves to observe the same conditions and should therefore all enjoy the same rights. Thus, from the very nature of the compact, every act of Sovereignty, i. e. every authentic act of the general will, binds or favors all the citizens equally. ${ }^{214}$

\subsection{The State of Society}

According to the doctrine expressed in the Philosophie sociale, with the exit from the state of nature and the institution of a civil society, through the social contract, man becomes a social being, that is "a man who lives together with his fellow human beings". ${ }^{215}$

Man lives with other individuals and interacts with them. Thanks to this social interaction, the human being is able to survive and overcome the concurrent lack of autonomy and self-sufficiency. But not just that. It is in society - in

213 Hobbes, Leviathan, 47 (I. 11).

214 Rousseau, Du contrat social, II. 4: [Par quelque côté qu'on remonte au principe, on arrive toujours à la même conclusion; savoir, que le pacte social établit entre les citoyens une telle égalité qu'ils s'engagent tous sous les mêmes conditions, et doivent jouir tous des mêmes droits. Ainsi par la nature du pacte, tout acte de souveraineté, c'est-à-dire tout acte authentique de la volonté générale oblige ou favorise également tous les citoyens] (Idem, The Social Contract, 28-29).

215 Dobruska, Philosophie sociale, 82. 
the state of culture - that the individual succeeds in developing and fulfilling his desires and abilities, intellectual and material, until he reaches the highest levels, through the exchange with other human beings:

His love for property, the sweetness of fortune, his taste, his appetitive faculty, make him unable to rejoice now in his primitive stage, and to settle for it. He needs society for the development of his appetizing faculty. He is no longer a sovereign being, self-sufficient, totally independent outside himself; he has become a dependent member of the great body of society. ${ }^{216}$

In this social body, which is society, man has the duty to provide for his own sustenance, but also the right to evolve according to his abilities, which for Dobruska vary from individual to individual.

At the same time, however, he must relate to others, also considering their needs and requirements. He can't act selfishly. He cannot only take from others to achieve his own selfish ends, but must also give, so that his fellow beings can in turn develop and evolve. In other words, social interactions between individuals in a democratic society must be based on the ethical principle of reciprocity, which we will discuss in more detail in the following chapter.

Therefore, the social man is also a moral being. He has two moral faculties: reason and feeling. ${ }^{217}$

Society, in Dobruska's vision, is a new whole or rather a sovereign and independent whole, spontaneously composed of the union of primitive individuals, who depend on each other for their livelihood and for the development of their material and intellectual capacities. ${ }^{218}$ People are all equal in terms of natural and inalienable rights. They are all social men and, at the same time, holders of rights.

\subsection{Social Context and Socialization Process: From the Individual Self to the Social Self}

Moses Dobruska's sociological gaze is fixed both on individuals, understood as members of a society, and on society as a whole.

216 Ibidem, 128: [L'amour des propriétés, les douceurs de la fortune, son goût, sa faculté appétitive développée, le rendent incapable de jouir maintenant de son état primitif, et de s'en contenter. Il a besoin de la société par ce développement de sa faculté appétitive, il n'est plus un être souverain, se suffisant à lui-même, totalement indépendant hors de soi, il est devenu un membre dépendant du grand corps de la société].

217 Ibidem, 115.

218 Ibidem, 134-135. 
This is a view that we can rightly define as "sociological", aimed at portraying individuals and society as they are and not as they should be, whereas the prescriptive character is instead proper to social philosophy.

This knowledge about the human being as a social being is multifaceted, complex and articulated on several levels, which we could call, using the terminology of today's sociology, micro, meso and macro.

The unit of analysis from which the sociological reflection of Dobruska starts - close in this respect to the liberal philosophical tradition - is the individual and not the group of individuals. Our author never speaks of social groups or movements as collective actors, although he denounces abuses of power and privileges based on belonging to certain social classes. Dobruska sees the individual, in a democratic society, not as a passive but as an active actor, capable of expressing his needs and desires and of fulfilling them.

The individual is also in a constant relationship and exchange with his fellow human beings, who are necessary for his material sustenance (his "selfpreservation") and for the improvement of his abilities, which today we will call self-realization.

This subject is not the rational actor of the liberal Adam Smith, who is free to act in different areas of social life, as if he were a single atom. On the contrary, he is strongly rooted in a specific socio-cultural context, regulated by very precise social norms. The set of these social norms, which for Dobruska represents what today we would call "structure", influences the behavior of individuals.

Let's now take a closer look at the three levels of analysis: the micro level focused on the individual, then the meso level, which focuses on the interrelationships between individuals and, finally, the macro level, which explores the influence of the social structure of the wider context in which the individual lives.

\subsubsection{At the Micro Level}

The individual with whom Dobruska concerns himself is the one who is active in the public sphere, both in the productive (working) and the political sphere. The analysis of men in the private sphere, in particular in the family, is almost completely omitted. This, at least in part, is why women remain in the background, if not absent (alas), in his work. With the distinction between the "public sphere" and the "private sphere", which was emerging in the intellectual debate at the end of the eighteenth century, women were relegated to the private 
sphere, in the role of wives and mothers. ${ }^{219}$ With a few exceptions - think of the already mentioned Olympe de Gouges and Claire Démar (1799-1833) - they disappeared from the public scene for almost a century, until the rise of feminist emancipation movements at the end of the nineteenth century.

Although Dobruska considers men to be endowed with the same rights, he is very careful to preserve individuality, which distinguishes one subject from another, in terms of needs, capacities, and desires. Some human beings may reach the highest perfection of their abilities, while others may not aspire to such a high goal. Some individuals will pursue the improvement of their economic situation until they achieve a life in luxury. Others, on the other hand, will prefer a more modest life in terms of material wealth, with a greater propensity towards the development of their own spirituality. ${ }^{220}$ This capacity for human development and improvement is only possible in society. Although Dobruska starts from the individual, his theoretical approach cannot be conceived within methodological individualism.

\subsubsection{At the Meso Level}

Since individuals in society lose their autonomy from the state of nature, they are obliged to rely on others for their own livelihood and survival.

According to Dobruska, individuals as social beings are forced to interact with each other, both for reasons of mere material survival and for the improvement of their intellectual and creative potential.

Our author emphasizes the importance of relationality, which for him becomes a duty. With a rhetorical question, Dobruska asks himself: "In the social state, is man bound by the duty of relationship towards his fellow men?". And the answer is, unfailingly, "Yes". 221

This conception of the individual has its roots in the Spinozian model. Spinoza had already placed an emphasis on the relationship, thus overcoming an essentialist approach to the human being, without embracing a holistic vision. ${ }^{222}$

219 Higonnet, Sociability, Social Structure, and the French Revolution, 101.

220 Dobruska, Philosophie sociale, 209.

221 Ibidem, 93: [Dans l'état social l'homme est-il tenu au devoir de la relation envers ses semblables? Oui].

222 See Ronald Breiger, Baruch Spinoza. Monism and Complementarity, in Sociological Insights of Great Thinkers: Sociology through Literature, Philosophy, and Science, ed. Christofer Edling and Jens Rydgren (Santa Barbara, CA: Praeger, 2011), 255-262; Emauele Costa, "Uno Spinoza 
As Juliana Merçon points out, Spinoza can be presented as a systemic thinker lato sensu:

The relational ontology that Spinoza proposes with his anti-substantialist vision of modal realities allows us to think of the individual as an open microsystem, whose existence depends on the interaction it maintains with other individuals. ${ }^{223}$

For the development of daily life and the stability of society, the interactions and bonds that the individual builds with his fellow human beings, in particular with those belonging to his generation, but also with those of past generations, are of crucial importance.

Although Dobruska never uses the term "family" in his entire work, and does not specifically analyze the functioning of it, he briefly dwells on the bonds between parents and children. These links are an important element of cohesion for society, not only because of the affective bond they express, but also because they pass on knowledge from one generation to the next. In this spirit, Dobruska cites The Spirit of the Laws of Montesquieu, which states that, in order to educate children, parents must be educated. In his attention to the transmission of knowledge from one generation to the next one, the influence of the Jewish world, from which our author comes, is also evident. According to Dobruska, parents have the task of directing and controlling the formation of children, telling them what they should read and what they should avoid. They should be aware of the content of the Universal Constitution, which represents "social education", while avoiding pseudo-philosophical essays: ${ }^{224}$

Fathers and mothers remove from the hands of your children these learned and harmful stupid things. Almost all of these books are full of twists gargles and contradictions, of truths and fairy tales, of light and darkness. ${ }^{225}$

The text that children must feed on is the Universal Constitution. In the last chapter of the Philosophe sociale, Dobruska states that the democratic regime will remain stable where the most suitable and capable representatives have been chosen to govern:

sistemico. Strumenti per un'interpretazione sistemica del pensiero di Spinoza," Rivista di Filosofia Neo-Scolastica 106 (2014): 525-535.

223 Juliana Merçon, “La filosofía de Spinoza y el pensamiento sistémico contemporáneo," Revista de Filosofía (Universidad Iberoamericana) 133 (2012): 87.

224 Dobruska, Philosophie sociale, 74.

225 Ibidem, 73: [Pères et mères, ôtez des mains de vos enfans ces doctes et dangereuses niaiseries. Presque tous ces libres sont tellement remplis d'entortillage et de contradiction, de vérités et de fables, de lumière et d'obscurité]. 
The father is born again in the son, the mother is born again in the daughter. Some generations die, others reproduce them; but man is always man, his regime is always the same, as stable as the earth. ${ }^{226}$

\subsubsection{At the Macro Level}

Dobruska understands very well how the social and cultural context, in which the envied were born and live, influences beliefs, behaviors, and habits, as well as the ways people interact with one another. It is the set of social and moral norms that prevails within a specific social organization that guides and forms the beliefs of individuals, their behaviors and their lifestyles, as we would say today. Among other things, the Philosophie sociale shows how, in the theocratic social organizations, in which the normative system coincided with the corpus of religious precepts of the sacred Scriptures, there were very different behaviors regarding, for example, sexual relations between men and women, and relations between genders, as well as culinary habits.

In other words, the set of religious precepts - which can be considered as an independent variable - has a direct influence in shaping the behavior of individuals, in regulating the daily life of individuals and in assigning specific social roles:

The inhabitants of Mecca may be Christians, just as the inhabitants of Rome may be Mohammedans, but the difference between Christ and Muhammad, the only difference between these two men, between the system of the Gospels and the Koran, is also the difference between the people of Rome and the people of Mecca; It is thus that even in the Indies, between peoples of one and the same nation, of one and the same character and climate, only the Gospels and the Koran produce the differences between them; since the missionaries of the Gospel made some Christians, while the missionaries of the Koran made others Muslims. ${ }^{227}$

226 Ibidem, 235: [ . . . car le père renaît dans son fils. La fille fait revivre la mère; des générations meurent, d'autres les reproduisent; mais l'homme étant toujours homme, son régime est toujours le même et demeure stable comme la terre].

227 Dobruska, Philosophie sociale, 196: [Les habitans de la Mecque pouvoient être des Chrétiens, aussi bien que les habitans de Rome pouvoient être des Mahométans; mais la différence entre le Christ et Mahomet, la seule différence entre ces deux hommes, entre le systême de l'Évangile et du Koran, constitue la différence entre le peuple de Rome et le peuple de la Mecque; c'est ainsi, que même dans les Indes, entre des peuples d'une seule et même nation, seul et même caractère et climat, l'Évangile et le Koran seuls produisirent la différence entre eux, en ce que les Missionnaires de l'Évangile firent chrétiens les uns, et les Missionnaires du Koran firent musulmans les autres]. 
In this passage Dobruska highlights well how there is no "extrinsic essence" that distinguishes the inhabitants of one nation from another. The same individual born in Rome in a Christian religious context would become a Muslim if he were born in a country where the official religion was the Islamic one and not the Christian one. This same individual would believe and act in his daily life according to the dictates of the Koran, not the Gospels. In other words, it is clear to our author that, in primitive theocratic social organizations, religions and their spiritual leaders ("the legislators") play a crucial role in what we today call "secondary socialization", that is, in the internalization, by the individual, of the beliefs, values, and social norms defined by religion and its charismatic leaders.

Dobruska emphasizes very clearly how the identities of individuals and their behaviors are built socially and culturally through the internalization of the religious normative corpus. It is the intuition of a more general sociological law, according to which the set of beliefs and the normative corpus - be it religious, metaphysical, or based on the "laws of nature" - influence and determine in part the behaviors and rules of daily life.

The set of rules, regulations and social sanctions therefore has an impact on individual behavior, customs, and practices in everyday life. On the other hand, such a context allows the individual what in the "state of nature" would not have been possible: the possibility to develop himself at the highest levels, to reach perfection, to increase and expand his appetite both material and intellectual. That is why the individual needs society:

I mean [. . .] to explain myself better: when I take away from man, whose instinct has been formed by culture, all the benefits of society and art, I send him back to his forest, to his cave, I force him to feed again on his roots and his acorns. Through the restitution of all the ancient benefits of the old state of nature, will he be able to concretely achieve his goal, the supreme good, the object of his research? Of course not. He needs bread now and not roots. His love for property, the sweetness of fortune, his taste, his developed appetitive faculty, make him unable to rejoice now in his primitive state and to settle for it. He needs society for the development of his appetitive faculty, he is no longer a sovereign being, which is enough to himself, totally independent with respect to everything that is outside him; he has become a member dependent on the great body of society, conforming to nature, all his rights and his advantages belong entirely to the new sovereign (society) and his individual preservation is thus transformed into the conservation of society. ${ }^{228}$

228 Philosophie sociale, 128 : [je veux dire [. . .] pour m'expliquer mieux: quand je retire à l'homme formé par la culture de son instinct, quand je lui retire tous les bénéfices de la société et de l'art., que je le renvoie à sa forêt, à sa caverne, que je le force a se nourrir de nouveau de ses racines et de ses glands. Par cette restitution de tous les bénéfices de l'ancien état de 
In other words, man obtains from society the possibility to expand his own capacities and material and intellectual desires. Here we have an echo of the thought of Jean-Jacques Rousseau in the Social Contract, about the advantages that man obtains when he passes from the state of nature to the state of civilization:

The passage from the state of nature to the civil state produces a very remarkable change in man [. . .] Although, in this state, he deprives himself of some advantages which he got from nature, he gains in return others so great, his faculties are so stimulated and developed, his ideas so extended, his feelings so ennobled, and his whole soul so uplifted, that, did not the abuses of this new condition often degrade him below that which he left, he would be bound to bless continually the happy moment which took him from it forever, and, instead of a stupid and unimaginative animal, made him an intelligent being and a man.

Let us draw up the whole account in terms easily commensurable. What man loses by the social contract is his natural liberty and an unlimited right to everything he tries to get and succeeds in getting; what he gains is civil liberty, and the proprietorship of all he possesses. $^{229}$

For both Dobruska and Rousseau, the passage, through the social contract, from the state of nature to the state of culture (or civilization, according to the expression of Rousseau) means the loss of some faculties and some rights but, at the

\footnotetext{
nature, pourroit-il actuellement atteindre son but, le souverain bien, objet de ses recherches? Non certes. Il lui faut désormais du pain et non pas des racines. L'amour des propriétés, les douceurs de la fortune, son goût, sa faculté appétitive développée, le rendent incapable de jouir maintenant de son état primitif, et de s'en contenter. Il a besoin de la société par ce développement de sa faculté appétitive, il n'est plus un être souverain, se suffisant à lui-même, totalement indépendant hors de soi, il est devenu un membre dépendant du grand corps de la société, conformément à la nature, tous ses droits et avantages appartiennent aujourd'hui en entier au nouveau souverain, (la société) et sa conservation individuelle se trouve ainsi changée en la conservation de la société].

229 Rousseau, Du contrat social, I. 8: [Ce passage de l'état de nature à l'état civil produit dans l'homme un changement très remarquable [. . .] Quoiqu'il se prive dans cet état de plusieurs avantages qu'il tient de la nature, il en regagne de si grands, ses facultés s'exercent et se développent, ses idées s'étendent, ses sentiments s'ennoblissent, son âme tout entière s'élève à tel point que, si les abus de cette nouvelle condition ne la dégradaient souvent au-dessous de celle dont il est sorti, il devrait bénir sans cesse l'instant heureux qui l'en arracha pour jamais et qui, d'un animal stupide et borné, fit un être intelligent et un homme. Réduisons toute cette balance à des termes faciles à comparer. Ce que l'homme perd par le contrat social, c'est sa liberté naturelle et un droit illimité à tout ce qui le tente et qu'il peut atteindre; ce qu'il gagne, c'est la liberté civile et la propriété de tout ce qu'il possède] (Idem, The Social Contract, 18-19).
} 
same time, allows the achievement of some advantages, not only in terms of personal development.

There is no doubt that Dobruska follows Rousseau here, although he does not mention his name. However, he differs from Rousseau's model in terms of the content of losses and gains that are made by moving from one state to another. On the one hand, for Rousseau, during the transition from the state of nature to civilization, man is transformed from a substantially "deficient" being into an intelligent one, who advances spiritually. In addition, in exchange for the loss of natural freedom and the right to everything he craves and desires to achieve, he obtains civil liberty and the right to property. For Dobruska, on the other hand, the man who passes from the state of nature to that of culture loses his independence and the ability to stay alone. He becomes dependent on his fellow men, with whom he is forced to enter into a relationship to ensure his survival. As Durkheim will say much later, with his concept of organic society in the De la division du travail social of $1893,{ }^{230}$ societies are formed because no individual is self-sufficient and autonomous any more: everyone depends on the other. In other words, according to Dobruska's conceptualization of multiple needs, each individual has different material or intellectual needs and will be able to contribute to society according to his or her abilities.

Through interaction with other individuals and societal institutions (schools, universities, cultural and political associations) the individual has the opportunity to fulfill all his desires and to develop faculties, both material and intellectual. His being can progress until it reaches the perfection of its material and intellectual skills.

Unlike Rousseau, who remains a political philosopher, and affirms the dichotomy between individual and State, Dobruska emphasizes the duality between individual and society. For this reason, too, Dobruska should be counted among the founding fathers of sociology.

Now that we have outlined our author's theory on the individual and on society, we will deepen in the following pages the different types of interactions between human beings living in a democratic society and we will ask ourselves what, in the Philosophie sociale, is the element of cohesion that holds a society together.

230 Emile Durkheim, De la division du travail social. Étude sur l'organisation des sociétés supérieures (Paris: Félix Alcan, 1893). 


\subsection{Forms of Social Interactions between Individuals: From Selfishness to Reciprocity}

The sociological thought of Dobruska conceptualizes different forms of exchange between individuals living in society. As we have just mentioned, interrelationships between members of society are necessary because, having abandoned their natural state, people are no longer autonomous, and are unable to provide for their own preservation and livelihood.

Dobruska theorizes two great models of interrelationships, which in Max Weber's (1864-1920) words we would now call two ideal-types: selfishness and reciprocity. These two models of interrelationships have antithetical characteristics and have completely opposite impacts both on other members of society and on society as a whole.

Reflection on forms of social interaction has been a fundamental theme of sociological thought, from classical authors to the present day. ${ }^{231}$ Special attention has been paid by many authors to reciprocity, understood as "the provision of services or the supply of material goods, with the expectation of having subsequently a return of services or goods in ways, quantities and timescales

231 In sociological thought, the concept of reciprocity has been a fundamental theme for various authors from the nineteenth century to the present day. Think for instance of Georg Simmel (1858-1918), who underlined the fundamental social meaning of reciprocity: "Aller Verkehr der Menschen beruht auf dem Schema von Hingabe und Äquivalent. Nun kann für unzählige Hingaben und Leistungen das Äquivalent erzwungen werden. Bei allen wirtschaftlichen Tauschen, die in Rechtsform geschehen, bei allen fixierten Zusagen für eine Leistung, bei allen Verpflichtungen aus einer rechtlich regulierten Beziehung erzwingt die Rechtsverfassung das Hin- und Hergehen von Leistung und Gegenleistung und sorgt für diese Wechselwirkung, ohne die es keine soziale Balance und Zusammenhalt gibt” [Georg Simmel, Soziologie. Untersuchungen über die Formen der Vergesellschaftung (Leipzig: Duncker \& Humblot, 1908), 590]. Karl Polanyi (1886-1964) dwells on three fundamental forms of integration defined as reciprocity, redistribution, and market exchange. Alvin W. Gouldner (1920-1980) analyzed the relationship between reciprocity and morality, but also the role that the stabilization of a social system fulfilled by reciprocity fulfills. For Gouldner, not only does the rule of reciprocity serve to stabilize the function of groups, offering additional motivation and reinforcement to behaviors of compliance with social roles, but it is also a starting mechanism, i.e. a mechanism, which helps to initiate new social interactions, functional in the early stages of formation of certain groups, before they develop. Howard Becker conceptualizes the homo reciprocus. Randall Collins considers reciprocity as the basic process that makes exchange possible and as an equivalent to the pre-conceptual solidarity of Durkheim. See Linda D. Molm, David R. Schaefer and Jessica L. Collett, “The Value of Reciprocity," Social Psychology Quarterly 70 (2007): 199-217. 
fixed by cultural norms"232 In sociological discourse, a distinction is generally made between two types of reciprocity: generalized and balanced.

"Generalized reciprocity", which takes place mainly within the family, "has no precise content, does not set time limits and does not even require that what is returned has the same economic value as what has been given". 233 "Balanced reciprocity”, which takes place outside the family networks, on the other hand, means "the exchange which provides for an equivalent refund in value calculated very precisely". ${ }^{234}$ A good example is the return of the invitation to dinner of friends, who welcomed us with respect and affection at home.

Let's take a closer look at these two antagonistic models of interrelation and the impact on individuals and the community as a whole.

\subsubsection{Selfishness}

After a detailed analysis of man and society, and their rights and duties, Dobruska focuses on the interrelationships between individuals. The first question is what selfishness is, what its distinctive features are, and why in the long run it is harmful to the community:

I also define selfishness as individual preservation. But let me explain: selfishness is a state that seeks to achieve its purpose. I mean, [the selfish person] satisfies his appetite on others while refusing to allow others to exercise it on him. The selfish person makes his ego the center of the relationships of all external and foreign activities; but it refuses to others the same exercise on him; thus an active state must be explained, which is not passive except for all that is outside of him. In a few words, in order to achieve his goal, [the selfish person] tries to be relative for others, and is not relative to them, that is to say, he rejects the reciprocity of the relationship. ${ }^{235}$

232 Arnanldo Bagnasco, Maurizio Barbagli and Alessandro Cavalli, Corso di sociologia (Bologna Il Mulino, 1997), 491.

233 Loc. cit.

234 Ibidem, 491-492.

235 Dobruska, Philosophie sociale, 95-96: [Je définis aussi l'égoïsme conservation individuelle. Mais je m'explique: l'égoïsme est un état qui cherche à atteindre son but: je veux dire satisfaire sur autrui sa faculté appétitive, pendant qu'il refuse à cet autrui l'exercice de la même. L'égoïsme fait de son moi le centre des relations de toutes les activités extérieures et étrangères: mais il refuse aux autres le même exercice sur lui, ainsi doit-il être expliqué un état actif qui n'est passif que pour ce qui est hors de lui. En un mot, qui pour arriver à son but, cherche a être relatif pour les autres, et à ne pas l'être envers eux, c'est-à-dire, qu'il refuse la réciprocité de la relation]. 
And again:

Selfishness is also individual preservation. However, the one who rejects the reciprocity of a relationship also rejects his duty and thus does not follow the law. Individual preservation is therefore the eternal principle, the fundamental basis of all justice and injustice. ${ }^{236}$

As I have argued in the previous pages, the man who lives in society, according to Dobruska's theory, needs his fellow human beings, and has the duty to enter into a relationship with them, for his own sustenance and to satisfy his appetite. The person who establishes a relationship in selfish terms is helped by other members of society to survive and to fulfill his material and intellectual desires, but when asked to return the services or goods obtained, rejects any kind of relationship. In other words, this person is able to take from others what he needs, but does not want and does not feel obliged to return the services or material, emotional, or intellectual goods that he received. And this way of interrelating with others is not only against the right enshrined in the Universal Constitution but is also a profoundly immoral action.

In the third chapter of the Universal Constitution, dedicated to Principle, Law and Selfishness, we read:

And as, in the state of society, man needs the relationship with his fellow men for individual preservation, and satisfaction of the fully developed appetitive faculty, the need establishes the duty of the relationship on his side and makes of this necessary reciprocity a right. ${ }^{237}$

Therefore, the person who refuses to interact reciprocally with others places himself outside the law. In so doing, he will, in the long term, be able to obtain goods and services that are greater than he would need. This amounts to an abuse of wealth and power by one individual against others, with the risk of creating a society in which one group dominate the remaining components and ask them to sacrifice their individual self. According to Dobruska, selfishness is an abomination because it "destroys the divinity of a common interest". 238

236 Ibidem, 98: [L'égoïsme est aussi la conservation individuelle, mais qui refusant la réciprocité de la relation, refuse son devoir, n'est pas en droit. La conservation individuelle est donc le principe éternel, la base fondamentale de toute justice et injustice].

237 Ibidem, 97: [Et comme, dans l'état de société, l'homme a besoin de la relation de ses semblables pour la conservation individuelle, et la satisfaction de la faculté appétitive développée, le besoin établit le devoir de la relation de son côté, et fait un droit de cette réciprocité nécessaire].

238 Ibidem, 99: [l'égoïsme, principe infâme, [. . .] dont il détruit la divinité d'un intérêt commun]. 
After destroying the common interest of the community, the selfish person pursues only his partial interest, with harmful consequences:

By introducing the hell of a partial interest, the true right is swallowed; and, by vomiting the abhorrent right of the strongest in society, one becomes guilty, and the other miserable, it confuses error with truth, obscures the simple path of nature and reason, complicates social philosophy, and deceives humanity in the science of living. ${ }^{239}$

To put this even more precisely:

Why, what does selfishness do? [The selfish person] refuses the right of others to himself; for this refusal, the duty of obedience to the principle of others is lost; therefore, his refusal is a true usurpation of the rights of others. So selfishness, this criminal substitution of rights, is really the usurpation of the rights of others [. . .] Morality is the opposite of selfishness, because the principle gains through morality itself, and loses through selfishness. ${ }^{240}$

In addition to usurping the rights of others, the selfish person also commits, according to Dobruska, an immoral action. Refusing to support another individual in their moment of need is a serious immoral act, regardless of the type of need: it could be a need linked to daily life but also to an event of exceptional drama, such as a natural disaster or an accident.

What's more, it is not just an immoral act that affects the individual, but one which affects society as a whole. More precisely, it causes the immorality of the State. We have observed that, for Dobruska, "the morality of the State is the consequence of individual morality". ${ }^{241}$ Therefore, selfish action is not just action against the law but is deeply unfair: it is action against social justice.

\subsubsection{Reciprocity}

Selfish action, which refers only to itself and rejects the duty of the relationship, is countered by acting according to the model of reciprocity.

239 Loc. cit.: [ . . . et en introduisant l'enfer d'un intérêt partiel, engloutit le droit véritable; et en vomissant l'exécrable droit du plus fort dans la société, rend l'un coupable, et l'autre misérable, confond l'erreur avec la vérité, obscurcit le sentier simple de la nature et de la raison, en compliquant la philosophie sociale, et en trompant l'humanité dans la science de vivre].

240 Ibidem, 104: [Car, que fait l'égoïsme? Il refuse le droit d'autrui sur lui; or, par ce refus, le devoir de l'obéissance au principe d'autrui, perd; donc son refus est vraie usurpation des droits d'autrui. Ainsi l'égoïsme, cette substitution criminelle des droits d'autrui [. . . ] La moralité est l'opposé de l'égoïsme, en ce que le principe gagne par elle, et perd par l'égoïsme].

241 Ibidem, 108: [La moralité d'état est la conséquence de la moralité individuelle]. 
By reciprocity, Dobruska means the exchange in which an individual provides services, goods, information, or emotional assistance in support of a fellow human being, or for his material or intellectual development. The assumption is that the other, sooner or later (usually in a rather short time), will reward him with similar goods and services. This obligation to reciprocate is a duty, which over time strengthens social ties.

The need for reciprocity arises from living in society. In this context, the needs of various kinds, which each individual has, are multiple and increasingly extend throughout life. The satisfaction of these needs can only take place thanks to continuous interrelation, based on reciprocity. We read in the Philosophie sociale:

In the social state, in which the multiple and more extensive needs cannot be satisfied or contained without the reciprocal and mutual assistance of all the members, everyone must contribute with all his means to the needs and to the satisfaction of the whole. No one can have the privilege of being dispensed from it, no one should interfere with it by preference, and no one can remain in a state of inertia or guilty neutrality, when it comes to the same interest in relation to the purpose (the principle): and certainly no one will remain a detached spectator, if he is awakened by an interest, which is the same as that of all the other members. ${ }^{242}$

In other words, all members of society, without exception, are expected to contribute to this mutual exchange, based on reciprocity, which serves to achieve the general interest of society. As I already mentioned, the ultimate goal of society is its self-preservation and the happiness of its individual members.

The obligation to reciprocate, the duty of relationships, is necessary, since "the conservation of each individual depends on the conservation of the entire social body". 243

In conclusion, according to Dobruska, reciprocity performs important functions for a social system: it guarantees the preservation of the individual self and the social one, it allowsfor the satisfaction of the multiple needs of individuals, it represents an antidote to the immorality of both the individual and the State, and it makes possible social cohesion and a society's stability over time.

242 Ibidem, 157: [Dans l'état social où des besoins multipliés et plus étendus ne peuvent être prévenus ni contenues que par le concours réciproque et mutuel de tous les membres, tous doivent concourir de tous leurs moyens aux besoins, et au contentement du tout. Aucun ne peut avoir le privilège de s'en dispenser, aucun ne doit s’y immiscer par préférence, et nul ne peut rester dans une inertie ou neutralité coupable ; quand il s'agit de l'intérêt égal relativement $a u$ but, (le principe) et certainement personne ne restera spectateur de sang froid, s'il est éveillé par un intérêt égal á celui de tous les autres membres].

243 Ibidem, 100. 


\subsection{Society and Its "Social Treasure"}

In his reflections on society, Dobruska seems to us to anticipate, even before Comte and Durkheim, what in sociology will be called, in the twentieth century, the "school of functionalist thought" or "functionalism" tout court. It will not be useless to recall here the definition of this theoretical orientation:

[Functionalism is] the analysis of cultural and social phenomena in terms of the functions they perform in a sociocultural system. In functionalism, society is conceived as a set of inter-connected parts, in which no part can be understood if it is isolated from the others. Any change in one of the parts is considered to cause a certain imbalance, which in turn produces further changes in other parts of the system and even a reorganization of the system itself. The development of functionalism is based on the model of the organic system that we find in the biological sciences. ${ }^{244}$

Dobruska conceives society as a group of individuals, who are not to be considered as isolated, independent and only rational atoms, but are interconnected with each other, dependent on each other for their livelihood and for the satisfaction of their needs. They are individuals capable of acting according to morality, following their own rationality but also their own feelings.

Although he does not use the term "function", Dobruska always stresses the ways in which each party - the members of society and society itself - interacts, the obligations and duties it must fulfil to meet the needs of individuals, to ensure happiness, and to keep the social system in balance.

Our author wonders how it is possible that the social system could remain stable, and immune to the mélanges monstreux of the society of the past, characterized by the absolute monarchy. This is a central theme in his reflection, as it will be for his successors, first for Comte and then for Durkheim:

Representative democracy, the only regime of the primitive sovereign, is also the only healthy one. The reason lies in this perfect balance, according to which each of its members - whatever their strength and capacity - receives a portion of nourishment equal to their own needs; that is to say, that there exists in the whole body a balance or an equilibrium of strictly identical interest, which assures them [i.e. the parties] a state of strength and health; from this also comes an advantage and the general good, which is nothing more than the sum of all the goods gathered by each one. We must therefore conclude that the regime (government) in which the general will is carried out relentlessly and representatively by the most capable and appropriate members is the only legitimate one. ${ }^{245}$

244 George A. Theodorson and Achilles S. Theodorson, eds., A Modern Dictionary of Sociology (New York: Crowell, 1969), 167.

245 Dobruska, Philosophie sociale, 234-235: [La démocratie représentative, seul régime du souverain primitif, est aussi le seul salutaire. On en découvre la raison dans cette pondération 
From this brief quotation we see how Dobruska compares society to a body composed of different parts, each with different needs. Thanks to the democratic process of representation, all members of this social system receive exactly what they need to meet their needs - no more, no less, quantum sufficit. The stability of the democratic regime over time is granted by the representatives of the citizens, who have been selected from among the most capable and most suitable individuals: they are perfectly familiar with the Universal Constitution and know what their citizens want.

While individuals are dependent on each other for social action, this is not the case under the law. In this context, individuals are to be considered as sovereign and independent entities, all having the same rights. Everyone has the right to citizenship. It is in no way acceptable for one individual to have more rights than another.

What is society's duty to itself? What are its assets, its "treasures" - what are its capitals, as we would say using the terminology of contemporary sociology? And how do these treasures differ from those of individuals? What are the obligations and functions of society towards its members, towards its citizens? In the Philosophie sociale we see the following:

What are the duties of the new sovereign, society, towards itself? They consist of the contribution of all cultural resources, together with the natural resources of each member, so as achieve the fullest satisfaction of the appetitive faculty, perfected and developed, the instinct formed by the principle, means whose union represents the property of the new sovereign, namely the social treasure, and which are obliged to lend each other mutual assistance with regard to the purpose required by the principle, that is, to be able to preserve themselves in the state of culture. ${ }^{246}$

parfaite, d'après laquelle, quelle que soit leur force ou - leur capacité, chacun des membres reçoit une portion de nourriture égale à ses besoins; c'est-à-dire, qu'il existe dans ce corps entier, un balancement ou équilibre d'intérêt rigoureusement égal, lequel assure leur état de force et de santé; d'où proviennent aussi l'avantage et le bien général, qui n'est autre, que la somme des biens réunis d'un chacun. Il nous faut donc conclure, que le Régime (gouvernement) dans lequel la volonté générale et sans cesse exécutée représentativement, par le membre le plus capable et le plus propre, est le seul légitime].

246 Ibidem, 138: [En quoi consistent les devoirs du nouveau souverain, la société, envers luimême? Ils consistent dans la contribution de tous les moyens de culture réunis aux moyens naturels de chacun de ses membres, afin, d'arriver par elle à la satisfaction la plus entière de la faculté appétitive perfectionnée et développée, l'instinct formé pour le principe, moyens dont la réunion présente la propriété du nouveau souverain, c'est-à-dire le trésor sociale, et qui sont obligés de se prêter un secours mutuel relativement au but exigé par le principe, c'est-à-dire, pour pouvoir se conserver dans l'état de culture]. This text is available also in the fragmentary German draft. See Appendix 3. 
Society is therefore obliged to support the development of all resources, both the cultural and natural assets of each individual, in order to achieve a very specific goal: to satisfy the desires of those who live together and to perfect their material and intellectual faculties.

In another passage of his work, Dobruska expands the concept of social treasure, that is, of the ownership of the new sovereign, affirming that it consists in the whole of "all the forces and means of culture which are added to the forces and natural means which preceded each individual”, that is, to the forces and natural means which the individuals possessed in the state of nature, before entering to live in society (in the state of culture). ${ }^{247}$

What exactly do the "forces and means of nature" possessed by each individual and the "forces and means of culture" consist of? In Philosophie sociale, these terms are not precisely defined. Rather, the author seems to take them for granted. It can be assumed, therefore, that they refer to a philosophical debate, well known at the time, between philosophes and revolutionaries. A debate that Dobruska could not but know.

We start with the individual and his "natural means" (moyens naturels) or natural resources. In order to get closer to the meaning of this concept in Dobruska's work, it seems useful to compare it with a text entitled Abrégé des principes de l'économie politique (Synthesis of the principles of political economy), attributed to the "Margrave de Bade", and published in Paris in 1772. It is a synthesis, authored by Karl Friedrich von Baden (1728-1811), of the Leçons oeconomiques of Victor de Riqueti, Marquis of Mirabeau (1715-1789). Both the lexicon and the main ideas are rather close to Dobruska's conceptions, and it is likely that the book was part of his readings. In the first section of the Abrégé, the natural needs (besoins naturels) and the natural means of man (moyens naturels de l'homme) are analyzed. The needs of man are manifold and follow a very precise hierarchy. The text first distinguishes between "needs" (nécessité), which in contemporary language are often referred to as "primary needs", followed by "necessities" (les besoins). The needs of man are essentially three: i) subsistence, ii) rest, which implies the need for security, and finally, iii) reproduction of the species. In addition to these three needs, there are two other categories of needs: iv) clothing; v) education to improve industry, and to use force according to the type of goods that are offered to us or that escape us. ${ }^{248}$

247 Ibidem, 143: [La propriété du nouveau souverain de la société, consiste dans toutes les forces et moyens de culture, qui se réunissent aux forces et moyens naturels antérieurs de chacun de ses membres].

248 Karl Friedrich von Baden, Abrégé des principes de l'économie politique (Paris: Chez Lacombe, 1772), 83. 
The natural means of man (moyens naturels de l'homme) are the constitutive means which belong to a person as an individual. These are divided into two types. First of all, the (physical) strength of man and all that follows from it, such as constancy in work, temperance, agility, must be considered. The second natural means is intelligence and everything that derives from it (such as industry, that is, being ingenious and industrious), combined with memory (souvenirs), and together with all activities and creations related to ingenuity and memory.

Such ideas, exhibited in the Abrégé des principes de l'économie politique, seem to us particularly suited to shed light on the term "natural forces and means".

Like the Abrégé, the Philosophie sociale also start from the needs of the individual and those of society, to arrive at the natural means of individuals, and those of culture, that are necessary to satisfy these needs.

Dobruska argues that in society there are multiple needs (besoins multipliés), which cannot be foreseen or fully met. That is, we have a hierarchy of needs, which must be briefly explained.

Initially, the needs for individual conservation must be met, which coincide with the first five needs exposed in the Abrégé - subsistence, rest, safety, reproduction, clothing. However, unlike Mirabeau, summarized by Karl Friedrich von Baden, who sees individuals as autonomous, rational and detached from the social context in which they live, for Dobruska - as a good "sociologist"men, when they live in society, are no longer autonomous entities. They therefore have another urgent need: to forge links with other members of society in order to survive and to achieve their highest goals.

This brings us to the last need, that of developing intellectual and material faculties, of perfecting our ingenuity until we reach the highest peaks - making human potential blossom - thanks to social life. ${ }^{249}$

249 Dobruska seems to anticipate by two hundred and fifty years the famous theory of the hierarchy of needs, elaborated by the psychologist Abraham Maslow (1908-1970) starting from the Forties of the last century. He has shown how individuals who have once managed to meet basic needs are driven to develop their inner potential and self-fulfillment. The levels of the hierarchy of needs are, according to Maslow's model, five: i) basic needs (food, water, sleep, sexual relations); ii) stability and security; iii) love, affection and sense of belonging to the community; iv) self-esteem including the need for prestige; v) development of one's own potential and self-realization. See Abraham H. Maslow, "A Theory of Human Motivation," Psychological Review 50 (1943): 370-396; Idem, Motivation and Personality (New York: Harper \& Row Verlag, 1970); Andrew B. Trigg, "Deriving the Engel Curve. Pierre Bourdieu and the Social Critique of Maslow's Hierarchy of Needs,” Review of Social Economy 62 (2004): 393-406. However, unlike Maslow, for whom the needs are innate and above all psychological, Dobruska emphasizes social needs. He also argues that the development and realization of human 
However, the analysis of Dobruska's needs does not end here: just as there is a hierarchy of needs for individuals, there is also one for society. Society first and foremost needs to survive over time, but also to be defended against external attacks.

Both the needs of individuals and those of society must be met, both by natural forces and means and by means of culture, the "social treasure". In fact, all individuals, through mutual assistance and mutual exchange, are required to contribute to the satisfaction of collective needs with all their means (moyens). ${ }^{250}$

We can now answer, with more knowledge of the historical and intellectual context, the question from which we started: what exactly are these forces and means of nature and culture?

We know that, through his passage into the state of culture, man partly maintains the faculties he had in the state of nature, but in addition broadens his expressive potential. The properties of man in nature, defined in the Philosophie sociale as the "primitive sovereign", consist of "all natural forces and means, which can lead man to his goal, required by the principle", ${ }^{251}$ that is, individual conservation. These forces and means are the physical strength and intelligence and ingenuity necessary for survival. Here, too, we see how the Abrégé helps us to shed light on the terms used by Dobruska. As I said above, the natural means, listed in the Abrégé, are made up of the force possessed by man and his intelligence, understood in the broadest sense (being rational, ingenious, able, having mnemonic abilities): in all likelihood, this is precisely the reference scheme through which we must also interpret the "means" put in place by nature in the Philosophie sociale.

As for the "means of culture", our author shows that they are all resources that allow material and intellectual development, such as housing, health care facilities, and buildings for education, but also education as such and wider cultural heritage. At this point we could see in Dobruska a precursor of functionalstructuralism, since he is interested in identifying the conditions and structures that satisfy individual needs. In the Philosophie sociale, these conditions are given by the set of all the natural resources of each individual, to which are

intellectual and material faculties can only occur in society through social interaction with other individuals and through the cultural means of society.

250 Dobruska, Philosophie sociale, 157.

251 Ibidem, 143: [La propriété du souverain primitif de l'homme, dans l'état de nature, consiste dans toutes les forces et moyens naturels qui peuvent conduire l'homme à son but, exigé par le principe]. 
added the resources or cultural assets that Dobruska defines, for the first time in the history of sociological thought, as "the social treasure" of society. ${ }^{252}$

Dobruska's final reflection on this "social treasure” concerns its distribution:

It is well demonstrated that no individual isolated in his "particular", or any other corporation, that exists in some new adopted unit, cannot acquire in society an unfair and more important interest. The new sovereign has no right to give or transfer to an isolated individual this new unfair and most important interest, whoever this individual is, not even to any corporation, under any title, i.e. the new sovereign can not abuse his "social treasure".253

The social treasure should not be distributed unfairly among members of society, favoring certain individuals or certain corporations, but fairly among citizens.

\subsection{Society: Rights and Duties}

\subsubsection{Public Contributions}

According to the Philosophie sociale, the new sovereign (society) can ask its citizens for various public contributions of a physical, moral, or patrimonial nature, but under two conditions.

The first condition is that contributions are required only for a specific purpose, namely for the preservation of society as a whole and for the full happiness

252 The idea that both the community and individuals can possess certain "treasures" or "capital" anticipates lines of thought, which in sociology will only be developed much later. Think of this in relation to the thought of Karl Marx (1818-1883) up to Pierre Bourdieu (1930-2002). Marx theorizes in Capital the different forms of capital that the two major social classes possess in a capitalist society - the capitalists have the economic and technological capital for the production of goods and services while the proletarians possess their mere "workforce" that they sell to the capitalists in exchange for a salary. The French sociologist Pierre Bourdieu expanded this conceptualization. According to him, in addition to economic capital, there are also cultural, social, and symbolic capitals.

253 Dobruska, Philosophie sociale, 146: [Quoiqu'il soit bien avéré qu'aucun individu isolé en son particulier, ni toute autre corporation sous quelque unité nouvelle adoptée qu'elle subsiste, ne puisse pas acquérir dans la société un intérêt inégal et plus important. Il n'est pas moins constant que ce nouveau souverain lui-même, n'a pas le droit de céder ou transporter à un individu isolé ce nouvel intérêt inégal et plus important, quelque soit cet individu, ni même à une corporation quelconque, sous quelque dénomination qu'elle existe, c'est-à-dire que le nouveau souverain ne peut abuser du trésor social]. 
of its members. No public contribution may be required for other purposes, such as for a particular interest of an individual or an association.

The government will not be able to demand contributions that hinder luxury or that are detrimental to personal needs. As we shall see later, Dobruska does not condemn luxury as a source of happiness for some members, nor does he propose any redistributive principles. The State is not obliged to redistribute economic and social resources, but has the task of guaranteeing equal rights. If the government were to demand the renunciation of luxury or need by an individual, it would be a tyranny. ${ }^{254}$

The second condition for a government's claiming a contribution is that it must be based on law. Moreover, the government cannot usurp the private assets of its citizens that serve their livelihood or their personal defense. For example, the government cannot require the individual to give up arms which serve his personal defense. ${ }^{255}$

\subsubsection{Defending Society: The Supremacy of the Strongest and Deception}

Dobruska considers whether the supremacy of the strongest and/or the use of deception are permissible instruments in a democratic society, or whether they should be bannedoutright.

The supremacy of the strongest and deception, which can represent an abuse of reason, are sacred rights, when they intervene "in defense of the principle", that is, for the preservation of the collective self (moi social). In this case, it is a possible course of action to sacrifice a minority of society in order to defend society as a whole.

If, on the other hand, the supremacy of the strongest and deception are used against the principle of the collective ego, they correspond to a murder, a true tyranny.

\subsubsection{Unit of Interest: The Ultimate Goal of Society}

The fifteenth chapter of the Universal Constitution sets out the principles that a legislator must follow with regard to the interests of the individual and of the State, so that his actions can be judged healthy and good for the whole of society.

254 Ibidem, 153.

255 Loc. cit. 
For legislation to be effective, it is necessary for the interest pursued by the State to be simple and unitary. The "legislator-philosopher" should not consider different corporations, groups, or social classes, but should start from individual human beings (être homme), who, as Dobruska has pointed out, are distinguished by the climate in which they live, by the food they eat, and by the habits they follow in their daily lives.

Although men are so different, they are brought together by an identical desire, which is constantly renewed. And this desire is the greatest possible prosperity. This prosperity is composed of the sum of the happiness of individuals:

It is indisputable that there is not a State that is perfectly happy in its entirety and in the parts that make it up, except that in which each member, individually and in itself, enjoys happiness, and whose analysis represents only the fundamental and natural basis of the uniformity of interests in the scale that is its responsibility, multiplied in an equal and generic manner, that is to say, general prosperity is but the sum of the happiness of each individual. ${ }^{256}$

In short, the State must pursue a single interest, namely social prosperity, consisting of the sum of the happiness of individuals.

Why, in many States, do we not enjoy the prosperity that the people of Europe so long for?

States that distinguish between public and individual interests are not prosperous. More precisely, these are States that pursue an interest that does not correspond to the sum of the happiness of their citizens. And this happens when new interests emerge from groups of people such as, for example, the interest of a part of the legislative body, of a king, constitutional or not, of any privileged caste. If the state also pursues these interests, then the overall interest will be different from the sum of the happiness of individuals. ${ }^{257}$

What happens if a State does not follow the natural principle but rather opposes it? What happens when two conflicting interests form the fundamental basis of legislation and the form of government? In this case there is a conflict of interest: the interest of the State is in opposition to that of individuals, and vice versa, bringing strong and inevitable tensions within society. ${ }^{258}$

256 Ibidem, 226-227: [Il est donc incontestable, qu'il n'y a d'état entièrement et parfaitement heureux dans son ensemble, et dans les portions qui le composent; que celui où chaque membre individuellement et en son particulier, jouit du bonheur, et dont l'analyse, ne présente que la base fondamentale et naturelle de l'uniformité d'intérêt dans son échelle, multipliée d'une manière égale et générique, c'est-à-dire, la prospérité générale, n’est que la somme réunie du bonheur de chacun des membres qui le composent].

257 Ibidem, 227.

258 Ibidem, 224-225. 
According to Dobruska, a truly democratic State, which wants to avoid continuous conflicts, must pursue the only general interest, prosperity, given by the sum of the happiness of individual citizens.

\subsection{Morality and Immorality of the Individual and Society}

The morality of the individual and that of society are the subject of the fourth and fifth chapters of the Universal Constitution.

According to Dobruska, the individual must not only be put in a position where he can support himself, but also one in which he can satisfy his desires and his material and intellectual appetite. The task and duty of society is to enable the citizen to achieve these fundamental rights.

People act to satisfy their desires and passions or to ensure their survival. But they can also act for moral reasons. The moral faculties of man lie both in rational discernment (la raison) and in feelings. Not always, however, do feelings and reason want the same things. If man listened only to his feeling, he would not perform certain actions, which he would by listening only to his own intellect, and vice versa. Indeed, feelings and reason are often at odds with each other. ${ }^{259}$

Dobruska defines morality as follows: "A voluntary partial relationship to the principle of the individual self of another". 260

Morals must be distinguished from law, that is to say, from the rules required by the State. We have seen that, for its own preservation, society imposes a specific rule on the individual: the duty of the relationship. In fact, the preservation of the individual depends on the preservation of the whole body of society.

When an individual asks for something from another individual for his own preservation, a voluntary relationship is established between them. Therefore, "he who gives to the poor food or clothing, does a moral action, because its preservation does not depend on his gift". ${ }^{261}$

If, on the other hand, an individual voluntarily sacrifices himself to defend society, he is not carrying out a moral action but acts according to the law, according to a rule that is recognized and sanctioned by the law. Why is that? Because his conservation, that of the individual in the state of culture, depends on the conservation of society (see Fig. 4). An individual citizen's moral behavior is only possible towards another citizen, not towards society as a whole.

259 Ibidem, 115.

260 Ibidem, 100: [Une relation volontaire, partielle, pour le principe du moi individuel d'un autre].

261 Loc. cit. 
Selfishness is against morality, since the selfish man takes from others without giving anything in return.
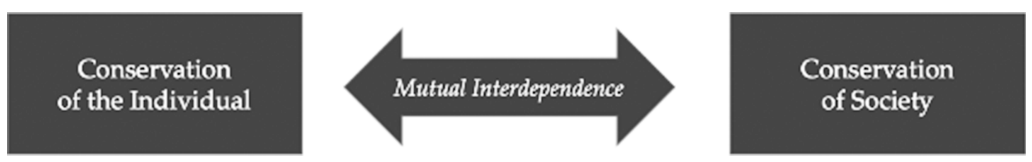

Fig. 4: The Mutual Interdependence between the Conservation of the Individual and that of Society.

Source: author.

We now come to the morality of society. As we have already mentioned, Dobruska believes that "the morality of the State is the consequence of individual morality". ${ }^{262}$ He continues his argument in this way:

\footnotetext{
Let me explain: if an individual has voluntarily saved another from the claws of a ferocious beast, if he has snatched him from the flames, if he has prevented him from being swallowed up by the force waves of a raging wave, if, finally, he has preserved his life from any other imminent danger, and if society rewards the individual for this particular voluntary act, this reward is a moral act of the society of the State. ${ }^{263}$
}

Therefore, the morality of the State is what recognizes and rewards individual moral action. This represents "the highest virtue of humanity, which it honors itself" ${ }^{264}$ If the State does not recognize and reward individual morality, then it acts immorally.

\subsection{The Boundaries of Freedom Between Self-Preservation and Lawlessness}

For Dobruska, the great adventurer who, from a provincial Jewish family, was able to climb the highest peaks of Viennese society and then throw himself into the intellectual fray of Paris, the ability to live as unhindered as possible and without external constraints is an essential principle. In his turbulent life,

262 Ibidem, 108: [La moralité d'état est la conséquence de la moralité individuelle].

263 Loc. cit.: [Je m'explique: si un individu en a sauvé volontairement un autre des griffes d'une bête féroce, s'il l'a arraché aux flammes, s'il t'a empêché d'être englouti sous les flots d'une onde couroucée; enfin, s'il a préservé ses jours de tout autre péril éminent, et que la société récompense cet individu de cet acte de relation volontaire particulière, cette récompense est un acte moral de la société d'état].

264 Ibidem, 111. 
he managed to transcend the limits of faith, wealth and, cultural horizons. His idea of freedom has traits in common with John Locke's thinking, but at the same time it differs from it by more than one point. The English philosopher, for whom Dobruska has a deep respect, speaks of freedom with an emphasis on the dimension of power. Freedom, for Locke, is the power to do or refrain from a particular action. In An Essay Concerning Human Understanding, Locke writes:

So that the Idea of Liberty, is the Idea of a Power in any Agent to do or forbear any particular Action, according to the determination or thought of the mind, whereby either of them is preferr'd to the other; where either of them is not in the Power of the Agent to be produced by him according to his Volition, there he is not at Liberty, that Agent is under Necessity. So that Liberty cannot be, where there is no Thought, no Volition, no Will; but there may be Thought, there may be Will, there may be Volition, where there is no Liberty. ${ }^{265}$

According to Dobruska, a freedom that is not anchored in the law does not apply to everyone. Only the physically and morally strongest citizens will be able to be free men, while the weakest and least capable spirits will be not only limited in their actions but also subject to the will of the strongest.

We read in the Philosophie sociale:

It is impossible that freedom, which Lo[c]ke defines as power, is a freedom that brings happiness to the masses of society, because nature has not given each of its members physical or moral power in equal measure; on the contrary, strength and weakness are unequally distributed.

From Lo[c]ke's definition we should conclude that the weakest in spirit and body would not have the same right to freedom. Since, according to his definition, freedom is power, a universal freedom cannot be understood, and it must necessarily be considered as individual freedom. But a freedom that is an individual prerogative, in society, is a tyranny, and a freedom that goes too far is lawlessness; Lo[c]ke could have said in the same way: freedom is tyranny, freedom is lawlessness. ${ }^{266}$

265 Locke, An Essay, II. 21. 6 (Idem, An Essay, edited by Peter H. Nidditch, 237-238).

266 Dobruska, Philosophie sociale, 174: [Il est donc impossible que la liberté, que Lo[c]ke définit puissance, soit une liberté qui fasse le bonheur de la masse de la société, puisque la nature n’a point donné à chacun de ses membres, une mesure égale de puissance soit physique ou morale, et qu'au contraire, la force et la foiblesse sont inégalement partagées entre eux. Toutefois, d'après la définition de Lo[c]ke, il nous faudroit conclure que les plus foibles d'esprit et de corps, n'auroient pas le même droit à la liberté. Or, puisque d'après sa définition, liberté est puissance, on ne peut entendre une liberté universelle, il faut nécessairement qu'il n'ait voulu définir qu'une liberté individuelle ayant pouvoir de tout faire. Mais une liberté prérogative individuelle, dans la société, étant une tyrannie, et une liberté poussée trop loin, étant licence; Loke pouvoit dire aussi justement: liberté est tyrannie, liberté est licence]. 
For Dobruska, the foundation on which individual freedom must rest is law, equal for all citizens. Only in this way can a democratic society guarantee individual freedom for everyone, regardless of their social class, religion, or level of education:

Law is the duty of the relationship according to the principle, where the principle is individual conservation. As a result, freedom is based on the principle of law, and anything that hurts freedom is necessarily contrary to the principle, and therefore not a right. ${ }^{267}$

Dobruska therefore makes two important reflections on the boundaries of freedom.

The first boundary, or demarcation line, of the individual's freedom, is selfpreservation. It is a question of defining the selection criteria that an individual has at his disposal in a democratic society.

In other words, the Philosophie sociale considers whether the individual can act according to his own tastes, inclinations, and in pursuit of pleasure, or whether social action should be delimited on the basis of some ethical principle.

A free individual has the possibility to choose between different behaviors and different activities. Some do him good and improve his well-being, while others do him harm.

As we have seen, freedom must be based on law, which in turn emanates from a very specific ethical principle, individual conservation. Consequently, on the basis of this principle, the freedom of choice of the subject is restricted. He cannot act only on the basis of his taste and his will. There is a very clear and distinct line of demarcation between what an individual can do and what a democratic society prohibits him from doing. In fact, there is an obligation not to harm oneself or, even more so, other individuals: "freedom in law consists in the choice between different beneficial things, and between non-harmful things". 268

The free citizen cannot choose that which jeopardizes his physical or mental constitution. He is not allowed to choose between destructive options. This would be contrary to the ethical principle of individual conservation, the principle on which the Universal Constitution drawn up by Dobruska is based. The

267 Ibidem, 177: [Droit est devoir de la relation pour le principe, donc le principe est la conservation individuelle. Il en résulte, que la liberté se fonde sur le principe du droit, et que tout ce qui blesse la liberté, est nécessairement contraire au principe, n’est pas droit].

268 Ibidem, 192: [Mais si nous avons une fois trouvé cette ligne de démarcation, alors nous verrons, que la liberté en droit ne consiste en autre chose que dans le choix entre les differens bons, et les différens non nuisibles]. 
example given in the Philosophie sociale concerns the choice of a sick person in convalescence, in front of a variety of meals. Among the foods you can choose from there are those that support your recovery, and that do not harm your health, or those that are tasty but that damage and prevent the healing process. If, as in Locke, the principle of freedom were independent of the ethical principle of self-preservation, the patient in question could easily choose the food that seriously affects his health. No one could stop him, he would act according to his will. According to Dobruska, this example clearly shows how the exercise of mere will can turn into an abuse of power - in this case against oneself - or into a license, that is, for example, a special preference given to a particular citizen or corporation.

The choice of a harmful food by the patient is a bad act, as it endangers his health and his life. In the chapter dedicated to freedom, Dobruska thus concludes his reasoning:

. . . bad choice becomes an act, an obedience against the principle, against the right, crime; freedom degenerates into license, the power to commit this act becomes tyranny, therefore it is necessary that [this act] be stopped by law and brought back to the beginning. ${ }^{269}$

The second boundary to individual freedom is the abuse of power, by one individual against others, or by the institutions of society, which, in doing so, contravene the law. A license then occurs.

One example of a license, on which Dobruska dwells more closely, is the one concerning religious institutions and, in particular, the imposition by a majority of their own religion. ${ }^{270}$ His criticism is directed against the Christian religion, which in eighteenth-century Europe was the most widespread religion. It is not the words of Christ, towards whom Dobruska shows deep respect, that are being targeted, but the ecclesiastic dogmas, instituted by the "priests, successors of Christ" (les prêtres, successeurs du Christ ${ }^{271}$ ).

According to the Philosophie sociale, the teachings of priests, according to which the kingdom of heaven had an absolute value and priority over the

269 Ibidem, 187-188: [ . . . le mauvais choix devient un acte, une obéissance contre le principe, contre le droit. Un crime; la liberté dégénère en licence, la puissance de commettre cet acte devient tyrannie, donc il faut qu'il soit arrêté là par la loi, et ramené au principe].

270 Ibidem, 181.

271 Ibidem, 46. 
earthly world, "teach to die and not to live". ${ }^{272}$ Dobruska is convinced that "there is no doctrine that is more dangerous for society, nothing that more hurts the principle of conservation of the self, both in the state of nature and in the social order. Yes, this religion is a clear usurpation of the rights of society, a murder of the principle". ${ }^{273}$

272 Ibidem, 180: [Celle-ci enseigne à mourir, mais non à vivre ; pour elle le ciel est tout; la terre n'est rien].

273 Loc. cit.: [Certainement il ne peut exister de doctrine plus dangereuse pour la société, nulle ne blesse autant le principe de la conservation du moi, dans l'état de nature et dans l'ordre social; oui, cette religion est une usurpation manifeste sur les droits de la société; un assassinat du principe]. 